This is an electronic reprint of the original article. This reprint may differ from the original in pagination and typographic detail.

Author(s): Ranta, Mette; Pessi, Anne Birgitta; Grönlund, Henrietta

Title: Young Adults' Conceptions of the Sacred in Finland Today

Year: $\quad 2017$

Version:

Please cite the original version:

Ranta, M., Pessi, A. B., \& Grönlund, H. (2017). Young Adults' Conceptions of the Sacred in Finland Today. Young, 25(1), 45-65. https://doi.org/10.1177/1103308816669212

All material supplied via JYX is protected by copyright and other intellectual property rights, and duplication or sale of all or part of any of the repository collections is not permitted, except that material may be duplicated by you for your research use or educational purposes in electronic or print form. You must obtain permission for any other use. Electronic or print copies may not be offered, whether for sale or otherwise to anyone who is not an authorised user. 


\title{
Young Adults' Conceptions of the Sacred in Finland Today
}

\begin{abstract}
This study examined young adults' perspectives on the concept of the sacred. Altogether 334 young Finnish adults aged 19-35 were studied through a self-report questionnaire. The participants' personal conceptions, reflections and experiences of the sacred were assessed with an open-ended question. Answers were classified in a data-determined content analysis using a thematic analytical approach. In addition, the study examined how these understandings of the sacred were related to subjective religiosity and how the definitions vary across gender. The findings suggest that the conceptions of the sacred mainly concentrate on individuality and personal issues, including personal opinion, rest and peace, but also close social relationships and the church as an institution. By differentiating the conceptions of the sacred, this study reflects cultural interpretations of what the sacred means and integrates the concept in the theory of young adulthood as a life course phase and in the sociology of youth.
\end{abstract}

Key words: sacred, young people, religion, gender, individualisation, identity, survey

\section{Introduction}

In the current youth generation in Finland, the understanding and perception of religion has changed in many ways compared with previous generations. When religiosity is measured according to engagement in traditional religious activities (for example, taking part in mass or praying) and belief (for example, in 'God' or in 'Heaven') (Niemelä, 2011), young adults in Finland are less religious than Finns in general. Another indicator of the changing status of religion among youth is church membership and relations to the church. Young adults have relinquished their church membership more rapidly than any other age group over the last decade. Half (53\%) of those who resigned their membership in 2013 were 20-39 years of age (Kirkon väkiluku, 2013, 2014). Altogether 75\% of Finns were members of the Evangelical-Lutheran Church in 2013, but only $68 \%$ of 20-29-year-olds and 65\% of 30-39-year-olds, despite the fact that as many as $83 \%$ of young people underwent confirmation at the age of 15 . The youth resign their membership because they do not find the church to be in line with their own beliefs and values (Niemelä, 2015). Young adults' 
religious identity differs from that of older age groups in that it is more open. They do not want to identify themselves with one specific tradition; they prefer to adopt an independent and active role in terms of their personal relationship with religion instead of seeing themselves as religious in a fixed or standardized way (Sjöborg, 2013).

Religion and spirituality have been studied relatively extensively, also regarding younger age groups. However, many of the often quantitative studies in sociology have focused on institutionalized religion and its rituals and teachings (Collins-Mayo and Dandelion, 2016; Sjöborg, 2013; Storm and Voas, 2012; Voas and Day, 2010) or on the connections between religion or spirituality and different issues such as sexual behaviour (e.g., Hull et al., 2011; Manlove et al., 2008), mental health problems (Huculak and McLennan, 2010), and substance abuse (e.g., Desmond, Kikuchi and Budd, 2010; Ford and Terrence, 2012; Isralowitz and Reznik, 2015).

However, young adults and religion should not be studied only in relation to certain activities, beliefs, and belonging to religious institutions, but in a holistic manner, aiming to understand individual experiences and reflections of religion and spirituality (e.g., Lövheim, 2012). For instance, in a recent study by King and colleagues (2014), the youth viewed spirituality as a means for understanding oneself and the world in addition to speaking of experiences of transcendence. Personal experience and individual religiosity have also been found important in relation to how satisfied young people feel concerning their confirmation (e.g., Ilg and Schweitzer, 2010) and how committed they are to the church as an institution in terms of church membership (Niemelä, 2015).

The need for qualitative data has also been emphasized to examine precisely how young adults are religious 'in their own way' (Sjöborg, 2013: 194). Furthermore, studies that combine this subjective starting point with social aspects, that is, the broader and more diverse conceptualizations of the relationship with religiosity, are needed (Lövheim, 2012; Sjöborg, 2013). Moreover, although a growing number of studies have emerged within several disciplines regarding the role of religion in youth development (Lerner, Roeser and Phelps, 2008), empirical studies concerning its relation to young adults' religiosity or spirituality have been called for (De Haan, Yonker and Affholter, 2011).

Limited attention has been paid to the sacred as an explicit starting point in studies on young adults' or even older adults' religiosity and spirituality. In all, only few studies on the sacred exist and the existing ones mostly represent fields such as comparative religion and anthropology (e.g., Idinopulos and Yonan, 1996; Knot, 2005; Lewis and Hammer, 2008; Paden, 1994). Moreover, the 
sacred has practically always been studied in regard to religious elements, while the sacred can be attributed also in non-theological contexts (Anttonen, 2000). The few recent studies that exist have covered very limited topics such as the media and popular culture (Deacy and Arweck, 2009; Lynch, 2007) and material, visual or spatial culture (e.g., Arweck and Keenan, 2006; Bergman et al., 2009; Knott, 2005). The concept of the sacred is rarely set in a larger theoretical or empirical context, and it has generally been used descriptively rather than analytically. Systematic empirical and theoretical studies on the topic of the sacred are indeed called for (Anttonen, 1996; Paden, 1996, 2009).

The present study examined the contemporary concept of the sacred as interpreted by young adults in Finland. The theme is studied through associated social and cultural reflections within interdisciplinary perspectives, integrating a dialogue between sociological youth studies and sociology of religion. The study draws on questionnaire data collected in 2011 from young Finnish adults aged 19 to 35 . The study investigated typical experiences, reflections and conceptions of the sacred expressed by these young Finnish adults, as opposed to focusing on the more general views represented by institutions, traditions and religious professionals.

The analyses included qualitative interpretations of the distinct definition of the phenomenon of the sacred. The study examined, first, prominent key meanings of 'the sacred'. Secondly, the study examined how the conceptions are associated with other themes in the field of religion, such as defining subjective religiosity. Additionally, we focused on the role of gender. In conclusion, we differentiated the conceptions of the sacred upon having reflected on the various cultural interpretations and subjective meanings attributed to the sacred and considered the related spiritual and value-oriented descriptions. In our study, we viewed the young adults' conceptualizations of the sacred as part of the life course phase of young adulthood. Figure 1 visualises the conceptual framework of the study and its intertwining elements: the developmental stage of young adulthood, contextual societal change with challenges from individualism to uncertainty, and concurrent religious change. These aspects are discussed in more detail in the following theoretical framework section. 


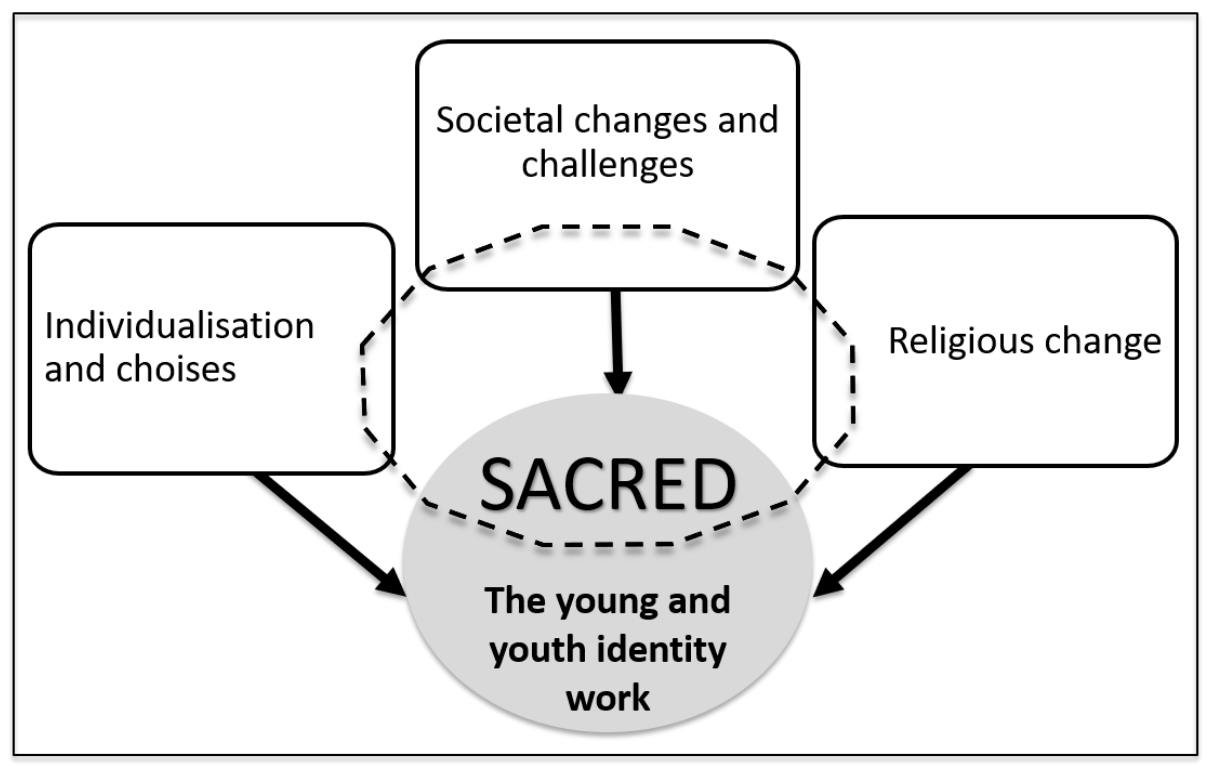

Figure 1. The Context of Youth Development

\section{Theoretical framework: Interpretations of the sacred and young adulthood development}

Religion in late modernity has increasingly become an arena of individual choice (Dobbelaere, 2002). Personal spiritual experience and personal truth are emphasized, even in institutional religions (Heelas, Woodhead et al., 2005; Roof, 1993). Traditional approaches to religion, such as denominations, institutions and dogma, are unable to grasp the variety of nuances and creative ways in which individuals live and understand spirituality. Approaches that aim to understand religion as lived, experienced and individually understood in everyday lives and practices have been referred to as lived religion or experienced religion. These approaches demonstrate the prominence of spirituality even in contexts of declining religious affiliation and changing public roles of religion (Ammerman, 2007; McGuire, 2008). Along with the privatization and the subjective turn of religiosity today, Finland is therefore an intriguing research setting with rather high private religiosity and very low public religiosity. Moreover, studying how individuals understand and express their spirituality regardless of traditional categories or indicators of religion helps us reach a better understanding of today's spirituality in its diverse forms and as it is understood and lived.

What is the relation between spirituality and the sacred? Scholars (e.g., Pargament, 2007: 32) have defined spirituality as a search for the sacred, characterizing the sacred as 'concepts of God, the 
divine and transcendent reality, as well as other aspects of life that take on divine character and significance by virtue of their association with or representation of divinity.' According to Roeser and colleagues (2008: 82), researchers should not restrict themselves to examining the validity of individuals' claims concerning the sacred (and spirituality), but should also consider the meanings and practices individuals attribute to the concept, how they search for it and how it influences their positive development; in other words, they should also consider the 'functional significance of these beliefs, attitudes and behaviours in regard to other indicators of healthy development.' Thus, examining current subjective conceptions of the sacred (as a key component of spirituality and religion) provides an opportunity to understand religion and spirituality as individuals think of it today. Also, subjective religiosity or spirituality are not formed in a vacuum but mostly reflect existing cultural categories of conceptions of the sacred, thus generally stemming from traditional religions as well as other phenomena. As such, subjective views inform us about contemporary religion and spirituality. Such views are precisely the focus of this study, and in the Discussion we will return to this aspect of the connection between positive development and the sacred.

The sacred, of course, is a classical concept, stemming from the most classical sociology of religion. For classical theorists of the sacred, such as Durkheim (e.g., 1995/1912; see also Jones, 1986) and Rudolf Otto (e.g., 1923), the functions and social processes related to the sacred were central. Durkheim defined the distinction between the sacred and the profane as an essential part of any religion. The sacred was something which was isolated and protected from the profane, the realm of everyday activities. According to him, religions express the nature of sacred aspects, rule how people should act in relation to sacred things, and coordinate sacred things to form a system. Durkheim also acknowledged individual forms of the sacred, but pointed out that these individual meaning systems often use ideas and principles of some established religion/s.

Otto approached the sacred from the viewpoint of individual experience and religious emotion (e.g., 1923). According to him, a holy reality results in a deeply religious emotion, a feeling of awe for something greater. The holy is the unspeakable other, which manifests itself in a non-rational experience, a mystery. This is the non-rational core of the concept of the sacred, which is reflected in feelings such as love, mercy and consolation.

In religion, communities define what is sacred and that binds them together. This communal aspect connects the concept of the sacred with the concept of identity. According to Durkheim (1995/1912), individuals who form a community feel they are connected to others through common 
faith and the way they think about the sacred and its relationship with the profane. Processes of collective identity, in general, include processes of both identification and differentiation. Collective identity and feelings of community can be created and strengthened through differentiations from others, that is, from 'outsiders' (e.g., Brewer and Brown, 1998). The concept of the sacred can be involved in these processes, both with respect to religious and secular identities.

Other further demographic categorizations are age and gender. For instance, youth is experienced and constructed differently between genders (Collins-Mayo, 2016), as is religion (Woodhead, 2013). There has been a tendency to see male practice as normative in understandings of what counts as religious and sacred. Studies which actively include a women's perspective often take in a much broader range of phenomena than fall within the purview of established sociological research. These phenomena include matters such as bodily and emotional wellbeing, the quality of intimate and familial relationships, the home, and sometimes the natural world (Sered, 1994). This is not surprising, as the gender labour division leaves women in most societies with greater responsibility for care, relationships, and domestic concerns in general (Woodhead, 2013).

Reflecting further Figure 1, the individuals in our focus, young Finnish adults, grow up in a culture of individualism and identity development, in which self-reflexivity and active self-monitoring, realizing and -actualizing have at least partially replaced collective and shared identities and goals. Young adults in contemporary society face an environment filled with constant social and cultural change, which makes the transition to adulthood very different compared with previous generations (Miles, 2000: 49). In addition, young adulthood as a crucial life course phase involves drastic changes as multiple, rapid and often simultaneous life transitions take place while developmental tasks are to be fulfilled (Almeida and Wong, 2009). Moreover, the criteria of achieving adulthood have become less apparent and subjective experiences are increasingly highlighted as young adulthood is seen as an important developmental period of its own, not merely a contrast to adulthood or an "in-between" phase (Settersten, 2003). However, according to life course research (Elder, 1998), diversity among individuals should be viewed in relation to their societal context, social relationships, agency and variation in developmental transitions. In post-industrialized Western society, young adulthood has changed significantly as transitions are frequently postponed, and young adults are not yet adapting to the normative responsibilities of adulthood. This stage, which has also been labelled emerging adulthood (Arnett, 2004), is dominated by identity exploration, instability, self-focused action and feelings of being in a transition phase that involves 
experiencing freedom and exploration on the one hand, and instability and insecurity on the other. In terms of identity development as a key psychological youth developmental task, in other words knowing who one is and what one wants and aims for, the age span of 25 to 35 years of age is especially critical. This quarter-life crisis roughly at age 30 causes stress due to insecurity and numerous life changes and transitions (Robinson, 2015). Inevitably, psychological maturation and identity development are often prolonged and pondered upon (Arnett, 2000; Furstenberg, 2001). For example, a recent study showed that almost half of Finnish 20-23-year-old young adults are still struggling with an unclear identity which might have detrimental consequences on wellbeing and finding one's place in the community and society (Marttinen, Dietrich and Salmela-Aro, 2016).

Young adults' religious beliefs and views on religion, in general, also change and develop throughout adolescence and young adulthood (Cobb, 2010: 371; Fowler, 2001). According to Fowler (2001), faith development during young adulthood reaches an individuative-reflective stage of faith. While responsibility needs to be taken for life decisions, similarly responsibility needs to be also taken for beliefs, examining these in light of their relevance to other commitments. As commitments and life decisions are all interrelated, young adults may experience new tensions, such as differences between their own perspectives and those of others. Young adulthood is a time when traditional religious beliefs as well as moral issues are questioned and faith is personalized (Fowler, 2001). As young adults often experiment with different identities, young adulthood is often accompanied by distancing oneself from religious authority and decreasing one's religious activity (e.g., Chan, Tsai and Fuligni, 2015; Uecker, Regnerus and Vaaler, 2007). Young adults may also question traditional beliefs and values learned in childhood (Denton, Pearce and Smith, 2008; Mikkola, Niemelä and Petterson, 2007; Niemelä, 2015). King and colleagues (2014) have even suggested that spirituality is a unique domain of human development including features such as finding significance, meaning, and the sacred.

\section{The present study}

\section{Research questions, data and methods}

Through the analyses of the present study, we aimed to gain a better understanding of today's young Finnish adults' personal conceptions and experiences of the sacred, and accordingly addressed the following research questions:

1. What kinds of experiences, reflections and conceptions of the sacred are most prominent? 
2. Do sacred components in life signify different things to young men and women when comparing by gender?

3. How are the conceptions of the sacred related to other themes in the field of religion? Is traditional religiosity related to the religion-related conceptualization of the sacred?

The data for this study were gathered from an extensive, written self-report questionnaire filled out by a nationally representative population sample in Finland, in 2011. A total of 1,285 participants (response rate 51\%; 57\% female) participated in the study, of which 334 (61\% female) were young adults 35 years of age or under (118 participants 19-25 years of age; 216 participants 26-35 years of age). In this study, we examine the data using these two young adult age groups. Furthermore, in order to investigate differences between young adults and the general population and to emphasize the critical age period of 25 to 35 years of age and especially age 30 in terms of identity exploration and development, participants were divided into two groups: under and over 30 years of age.

The majority $(66 \%)$ of young adults lived in urban areas; $36 \%$ had completed a tertiary educational degree, half (53\%) were employed, and $29 \%$ were in education at the time of response. The questionnaire included questions focusing mainly on issues of welfare and well-being. Religious themes were minor in comparison, and the question in focus at present —on the personal conceptions and experiences of the sacred-was the only open-ended question. It was formulated as follows: "Please tell us what the sacred, sacredness means to you? Where and how can you experience it?" This question was followed by a few blank lines for the participants to fill in regarding their personal conceptions and experiences of the sacred.

Our qualitative data were treated in the following manner. The answers given were classified within a data-determined content analysis, which resulted in altogether fifteen themes. Thereafter, the answers were classified into one or, in most cases, several of these fifteen data-determined categories using a thematic analytical approach. The fifteen classification categories were named: Nothing, doubt, difficult to say, difficult (0); Nature (1); Rest, peace, the home as a location (2); Belief, religion (3); Love, close ones, home with family (4); Death, grave (5); Art, music, science (6); Human dignity, new life, children (7); Location, church, institution (8); Ritual (9); Finland, independence (10); Individual, myself, my opinions, thinking (11); Others, helping, contact (12); 'The sacred' as a concept (13); and Health (14). A limitation, although it being also a significant contribution of the study, is the fact that the perceived meanings of the sacred were measured with an open-ended question; thus, the first interpretation mentioned may have primed further answers. Moreover, the answers were vastly heterogeneous and the categorization on its own would have left 
out important, detailed information concerning qualitative aspects. Therefore, in addition to the categorization of the data, this study also focused on interpreting the discourses on the meanings.

Subjective religiosity was assessed with the following questions: 1) "Overall, how religious do you perceive yourself to be?" —with multiple choice options being "very strongly religious / quite strongly religious / fairly religious / not strongly religious / not at all religious"; and 2) "Regardless of how religious you perceive yourself to be, how spiritual would you say you are?" -with multiple choice options being "very strongly spiritual / quite strongly spiritual / fairly spiritual / not strongly spiritual / not at all spiritual."

Traditional, private religious practice was assessed with the following question: "How often do you pray?" — with multiple choice options being "daily / at least once a week / at least once a month / at least once a year / less than once a year / not at all in recent years." Contemporary religious practice — be it private or more social—was assessed with the following question: "How often do you practice meditation and meditative health exercise (for example, tai chi or yoga)?" —with the multiple choice options being the same as for the previous question.

The quantitative analyses of the categories were conducted in Multiple Response Sets and using Bivariate analyses in SPSS (Version 22) with z-tests for gender and religiosity comparisons adjusted for pairwise comparisons using Bonferroni correction.

\section{Findings}

\section{Young adults' conceptions of the sacred and differences between age groups}

The results of the descriptive analyses of young Finnish adults' conceptions of the sacred are shown in Table 1. The results show that, among these young adults, the conceptions of the sacred differed in numerous ways as the distribution across the categories was broad and answers often suited more than one category. Both young Finnish adults as well as the general Finnish population responded to this open-ended question enthusiastically. In the general population data, 833 participants (65\%) responded to the question. In the young adulthood data, altogether $232(70 \%)$ of young adults aged 19 to 35 years responded. A total of 473 conceptions were mentioned in the data of the whole young adult population (19 to 35 years of age) and 1,835 conceptions in the total general population representing all ages. There were no significant differences among the participants who did or did 
not respond to this question in regard to living situation (urban versus rural) $\left(\chi^{2}(2, N=334)=.67, p\right.$ $=\mathrm{ns})$, educational level $\left(\chi^{2}(4, N=334)=7.33, p=\mathrm{ns}\right)$, or life situation $\left(\chi^{2}(2, N=334)=4.00, p=\right.$ $\mathrm{ns})$.

Insert Table 1. approximately here.

The replies by young adults often reflected thoughtful contemplation and philosophical depth. For instance, 'To me, the sacred means understanding the fact that we are all connected to each other (the entire universe), and living with this truth every second. One can sense the sacred within oneself and in others, wherever and whenever.' $(\mathrm{F}, 31)^{\mathrm{i}}$; and,

'To me, the sacred means the humanity that joins us all together and goes beyond all egos, awareness, consciousness of connection, experiencing and implementing. It is experienced most easily among others also concerned with the tricks their egos are playing and in changed states of the mind.' (F, 27)

The replies often included various intertwined elements and were categorized accordingly. For instance, the following quotation was categorized into altogether five categories, specifically, Belief, religion (3), Human dignity, new life, children (7), Nature (1), Love, close ones, home with family (4), and Individual, myself, my opinions, thinking (11):

'The Holy Trinity is sacred. The people created by Him are sacred. I can experience the sacred in the nature created by God when I experience His presence; also, alone at home and sometimes among friends. To me, the sacred represents to some extent the opposite of the increasingly growing evil in society.' (M, 26)

Intertwined elements could also be identified when more traditional, institutional elements and personal ponderings were mentioned side by side:

'To me, the sacred is Jesus, God and the Holy Spirit, but on the other hand, also space. For me, the sacred is a thing or a person, such as the Bible or Jesus. On the other hand, nature is a respected, even sacred thing. Often, nature helps us find a space where we can experience the sacred.' (F, 29) 
In the general population data including participants of all ages, the highest frequency categories were mainly Rest, peace, the home as a location (2) (31\% of participants), Nature (1) (29\%), andin the rather traditional manner-Location, church, institution (8) (28\%). Among the younger participants (19-35 years of age), the highest frequency category concentrated also on subjective and personal issues concerning the individual, that is, oneself and one's personal opinions and thinking (28\%) (Individual, myself, my opinions, thinking (11)):

'The sacred is something big, respected, and a secret. To me, God is sacred. But also everyday personal things can be sacred and one does not want to share them with anyone other than close ones whom one trusts. The sacred can be experienced in everyday life, everywhere: at home and in difference places such as the church, in nature, in one's own mind, and so on.' (F, 31)

However, young adults' experiences and views of the sacred also resemble those of older respondents; the second and third most popular categories with the younger respondents were rest and peace (Rest, peace, the home as a location (2)) (25\%) and religion and church as institutionalized and a physical location (Location, church, institution (8)) (25\%). For instance:

'Sacred means is quieting down at God's word, the Bible, and explaining it. The sacred and sacredness are religious concepts that are also present in everyday life, although one usually stops at them only on holidays. Sacred things (God, Jesus, the Holy Spirit, etc.) bring peace, joy and freedom. It's almost too difficult to explain. ;-)' (F, 25)

Sometimes the conceptions included a social aspect as well:

'The sacred means becoming aware of the presence of God, in Christianity. I can experience it at church/congregational events, in the middle of nature, or together with others while praying. A leisurely ambiance is important for experiencing the sacred.' (F, 26)

Interestingly, in both young adult and general population samples, religious elements were not necessarily seen to include personal relations. For instance, 'I am an atheist. But I respect everyone's convictions.' (M, 53); 'If something is sacred, one should not break, damage or otherwise terrorize it and it should be respected even if one does not personally care about it.' (M, 29); and, 
'Religious places — churches, chapels, mosques - are holy places to some. Not to me, but I respect others' thoughts on the sacred and therefore I want to behave politely in these places. For me, the sacred means personal inner peace, a good condition, almost the same as happiness.' ( $\mathrm{F}, 25)$

However, not all shared this viewpoint: 'I cannot experience the sacred, because it is connected to religions.' $(\mathrm{M}, 45)$

Closely following in the most popular categories among the younger participants were Love, close ones, home with family (4), but also doubting, and interpretations of insignificant meanings (Nothing, doubt, difficult to say, difficult (0)) (both 23\%). For example, 'The sacred = family' (F, 29); 'Love is sacred' (M, 32); 'Nothing really' (M, 30); 'Nothing, if we think it relates to religion; but some matters are sacred without having anything to do with religion, like traditional (family) values.' (M, 33). On the other hand, for participants over 30 years of age, Rest, peace, the home as a location (2) (33\%), Nature (1) (31\%), and Location, church, institution (8) (29\%) were more prominent.

When young adults were divided into two sub-groups (19-25-year-olds and 26-35-year-olds), the analyses revealed that the younger age group gave more answers in the Nothing, doubt, difficult to say, difficult (0) (28\% versus 18\%), Location, church, institution (8) (27\% versus 22\%), and the 'The sacred' as a concept (13) (24\% versus 13\%) categories. On the other hand, compared to the younger age group, the older young adults (26-35-year-olds) gave more answers in the Rest, peace, the home as a location (2) (34\% versus 17\%) and the Nature (1) (24\% versus 16\%) categories. Both young adult age groups (19-25-year-olds and 26-35-year-olds) portrayed individuality in their perspectives of the sacred (Individual, myself, my opinions, thinking (11)) (27\% and 29\%, respectively). For older participants (over 30 years of age), perspectives reflecting doubt (Nothing, doubt, difficult to say, difficult (0)) were significantly less prominent (only 16\% of participants), as were individuality and subjective and personal issues (Individual, myself, my opinions, thinking (11)) (only $19 \%$ of participants).

\section{Gender differences in definitions of the sacred}

The distribution of the gender groups across the categories of conception is displayed in Table 2 . Concerning the general population sample, there were significant differences between men and 
women according to our $z$-tests of significance $(p<.05)$ ii . In the categories of conception, $25 \%$ of men and $35 \%$ of women gave answers related to the Rest, peace, the home as a location (2) category. Of the women in the general population sample, on the other hand, up to $37 \%$ gave responses related to the sacredness of the Nature (1) category compared with only $16 \%$ of men.

Religion-related views of the sacred seemed to be shared by both men and women. For women in the general population sample, a third (31\%) experienced and viewed the sacred to be related to the church as an institution (Location, church, institution (8)) (24\% of men). On the other hand, the sacredness of the individual and individual thinking were emphasised equally by both men and women: $20 \%$ of women and $22 \%$ of men gave responses in the Individual, myself, my opinions, thinking (11) category. Among women in the general population sample, only $14 \%$ gave responses representing doubt (Nothing, doubt, difficult to say, difficult (0)) compared to $22 \%$ of men; such doubt is much more typical for Finnish men than women.

\section{Insert Table 2. approximately here.}

Among young adults in general (less than 30 years of age), no statistically significant differences were found between men and women. Responses in the Individual, myself, my opinions, thinking (11) category were prominently represented by all (29\% of men and $28 \%$ of women). For instance, 'The sacred means peace and it is personal, my most own.' (F, 34); 'The sacred is a [...] very personal matter. One can experience it wherever and whenever one wishes.' (M, 24); 'The sacred comes from within, from oneself [...].' $(\mathrm{F}, 34)$.

Furthermore, for men, the following responses fit the doubt (Nothing, doubt, difficult to say, difficult (0)) and church as an institution (Location, church, institution (8)) categories (both 24\%). For example, 'The church is a sacred place; there I can experience the sacred.' (M, 30); and,

'Sacred is a swear word when it is used for something [...] beyond the real world that turns out to produce mainly negative energy in those who dare to examine it reasonably. A good thing may thus turn into a burden when it is not dared to be questioned or developed.' (M, 26) 
The women's responses were often in the Rest, peace, the home as a location (2) (27\% of women) and Nature (1) (26\%) categories. For example, 'Nature is sacred; it can be felt deep in a forest or by a lake or sea.' (F, 30); and,

'To me, the sacred represents some thing or some place that is very important to a person; for instance, to me forests and nature are sacred places where one can calm the mind while moving around in them.' $(\mathrm{F}, 30)$

Interestingly, young male participants were likely to give answers related to the two categories of Human dignity, new life, children (7) and Others, helping, contact (12) (both 11\%). For instance, 'Life is sacred. Things, issues, objects and such are not. Some values are sacred, but they also change as society changes/develops.' (M, 24); 'Human dignity is sacred, life is sacred. I see the greatness and miracle of life every day in my children.' (M, 30); and, 'Sacredness means helping others without self-interest.' (M, 26).

\section{Relation between religiosity and conceptions of the sacred}

As for religiosity, $4 \%$ of young adults aged 19 to 35 years perceived themselves as 'very strongly religious', 5\% 'quite strongly religious', 23\% as 'fairly religious', 34\% as not strongly religious and $34 \%$ as not at all religious. Nevertheless, and interestingly, $40 \%$ of young adults simultaneously perceived themselves to be 'fairly spiritual' and $19 \%$ as 'quite strongly spiritual,' despite their levels of religiosity. Religiosity and spirituality were significantly correlated.

Of the young adults, $22 \%$ reported praying daily or at least once a week, while altogether more than half $(55 \%)$ of the young adults had prayed less than once a year or not at all in recent years. Meditative practice was also less common, although a small proportion reported it to be of significance for them; almost two-thirds $(72 \%)$ had not practiced these types of spirituality in recent years or less than once a year.

Insert Table 3. approximately here.

The young adults were categorized into four religiosity groups (Most religious / Fairly religious / Fairly unreligious / Most unreligious) based on their subjective levels of religiosity, spirituality and praying (in the form of traditional religious practice) due to their high correlations (Table 3). The distribution and significant differences between the groups' categories of conception, measured 
according to $z$-tests of significance $(p<.05)^{\mathrm{ii}}$ are displayed in Table 4 . More than half $(57 \%)$ of the most religious young adults expressed conceptions of the sacred in the Belief, religion (3) category and further conceptions related to the church as an institution (Location, church, institution (8)) (39\%); in regard to the latter, the responses of the most unreligious showed less relation (14\%). The unreligious young adults tended to describe conceptions that fit the Nothing, doubt, difficult to say, difficult (0) category. There were no significant differences between the prominence of conceptions of the sacred related to the Rest, peace, the home as a location (2) or Love, close ones, home with the family (4) or Individuality, myself, my opinions, thinking (11) categories, all being very important to the whole young adult population sample irrespective of religiosity (roughly 20-30\%).

Insert Table 4. approximately here.

\section{Discussion}

The aim of this study was to interpret the distinct definitions of the phenomenon of the sacred expressed by young adults in Finland today. The qualitative nature of the data illustrates their considerable efforts to answer the questionnaire's open-ended question concerning their notion of the sacred, yielding numerous types of responses. According to our knowledge, this theme has not been explored in Finland and international research on the topic is also scarce, along with largescale studies with quantitative methods on religion and gender in general (Woodhead, 2013). In this section, we would like to further discuss the analytical definitions of the sacred given by the young adults, also in relation to youth life course development.

The vast majority (70\%) of young adult participants, regardless of their religiosity, replied to the question regarding their conception of the sacred. There was no significant evidence of anomie or illiteracy regarding the sacred, with the category for sacredness meaning nothing showing a very small representation. These young adults clearly felt the concept of the sacred to be interesting and meaningful. Apparently, traditional categorizations or identifications of religiosity do not capture young adults' religiosity as lived, as suggested among others by Lövheim (2012) and Sjöborg (2013). These two approaches of traditional religion (dogma, institution, affiliation) and personal spirituality (sacred, experience, subjectivity) can be viewed as different categories in our results. Although they intersect in the experiences of some respondents, there seem to be no connections for 
others. For most young adults in our data, personal experiences of the sacred are not viewed as religiosity despite their transcendental and spiritual elements. In contrast, our qualitative methodology for investigating individuals' conceptions of the sacred seems to provide a means to effectively assess a dimension of experienced religion or spirituality.

The responses of the young adults were even more versatile than those of older age groups. Individual viewpoints and subjective experiences were central, illustrating a subjective turn of values and religiosity in the developmental stage of young adulthood. However, experiences were also emphasized in the questionnaire's question itself, which may partly explain why participants responded largely in regard to their subjective experiences; the question asked: "[The sacred...] Where and how can you experience it?"

In addition to subjectivity and individual emphasis, the answers also depict relatively strong traditional dimensions within young adults' conceptions of the sacred. The dimensions of the sacred that have been analyzed by classical theorists (e.g., Durkheim, 1995/1912; Otto, 1923) decades ago continue to be central for young adults today. Aspects of transcendence and the church as an institution are strongly present. This is not surprising in a country where the Lutheran state church continues to have a strong impact on culture and the Finnish population despite declining levels of traditional practice and belief. Furthermore, the responses reflect classical communal aspects of the sacred, relating to supporting communities (e.g., Durkheim 1995/1912), love and other people, and viewing all people as sacred and connected to each other and something greater. The answers also reflect emotions such as the experience of awe and mystery (e.g., Otto, 1923), which are classical conceptual dimensions of the sacred. Overall, respondents' emphasis on subjectivity and individuality intertwined with traditional content; the sacred was described as being something very personal, a choice even if it might have a lot to do with traditional religious elements.

All in all, dichotomies in general do not yield accurate descriptions of the reality of religions (e.g., Collins, 2008). Rather, religiosity and non-religiosity, tradition and subjectivity, as well as communality and individuality can be seen to form continuums. Further qualitative studies are called for in order to better understand the complex and intriguing ways in which young adults experience, understand, and combine these continuums. Interestingly, there were no significant differences between female and male respondents under the age of 30 . This might reflect sacred as being strongly defined by youth life course development instead of gender roles, which have become less distinguishable and more flexible over time (Cobb, 2010). However, in the whole data 
gender differences mirrored classical gender division of labour (e. g. Woodhead, 2013) as women gave significantly more answers than men related to the home and nature.

Personal pondering, reflecting a sense of personal sacredness, lies at the core of our findings. The individual's sense of authenticity was indeed often emphasized, in other words realizing and knowing one's potential and then acting on that potential, or intuitively being what one is (Starr, 2008). In psychology, authenticity refers to the consistency between three levels: 1) a person's primary experience, b) symbolized awareness, and c) outward behavior and communication (Barrett-Lennard, 1998: 82). In philosophy (e.g., Heidegger, 1962), authenticity concerns critical participation in life: critical assessment of how one is different, unique and what is true for the self. For example, 'Something is valuable in itself and one should not wound its integrity; one can sense the sacred anywhere, if one stops for a moment and senses the surrounding world.' (M, 32); 'To me, my own moral conceptualizations are sacred, uppermost judgment.' (F, 26); 'The sacred is probably the same as stability; it continues while surrounding things change.' (M, 29); and 'Sacredness can almost only be experienced by living; it may sometimes mean quietness and peacefulness, sometimes noise and haste, but usually a variation of these.' (M, 19). In sum, our study relates to the search for authenticity; as youth ponder on what is sacred for themselves, they portray selfdiscovery and consistency, but also a self-responsible form of life allowing a (potentially) fuller, richer and more differentiated life and mode of existence, along the lines of Taylor (1991).

Our results also reflect the developmental stage of young adulthood, where developing one's individuality is especially crucial. In terms of the topics and themes which young adults underline as sacred, these may play a vital role in positive youth development, along with the sacred itself as a vital resource in the transition to adulthood. On a practical note, these are issues which should be supported to promote development and wellbeing during young adulthood. This could signify, for example, discussions in schools on students' own beliefs, values and identity beyond the traditional study of religion, supporting normative youth life course development.

In conclusion, sacred can be identified as a tool for normative youth development during societal and religious change, as was hypothesized within Figure 1 in the Introduction and to what the study results adhere to. The sacred is used in youth identity work in relation to all three overarching, surrounding phenomena. Religion - from the lived or experienced religion perspective - can be seen as a cultural resource that enables personal orientation and transformation, and helps in "converting the chaos of the world into order" (Henriksen, 2016: 39). As such, religion, and the 
sacred as a resource in these functions of religion, can provide essential means for key developmental tasks in emerging adulthood in a societal context dominated by identity exploration, instability, and insecurity. Although the perspective of young adults in our data can be viewed as individualistic, these individuals use the concept of sacred also in relation to other people, responsibility, and respect. Such functions come close to classical perceptions of functions of religion and functions of the sacred as communal. The concept of the sacred can also be seen to bridge the individualistic approach of the young adults with questions related to others, communities, and relationships, as it validates viewpoints to them in an experiential, individually chosen manner. As such, it represents religion interwoven with human practice, orientation to oneself, others, and the world, in a life situation of uncertainty (see also King et al., 2014).

Our study also demonstrates how conceptualizing the sacred, as experienced and understood by the individual, provides a window to spirituality. The interdependencies of the individual's conception of the sacred, lived religion and religiosity are an important area for future research. Understanding these interdependencies can further develop and intensify our understanding of the life course stage of young adulthood and the symbolic status of the sacred in young peoples' lives today. 
Table 1. Total Distribution in Meaning Categories of Responses

\begin{tabular}{|c|c|c|c|c|c|c|c|c|}
\hline & \multicolumn{2}{|c|}{$\begin{array}{l}\text { Entire sample (all ages) } \\
\qquad(n=1,835)\end{array}$} & \multicolumn{2}{|c|}{$\begin{array}{l}\text { Age } \leq 30 \text { years } \\
(n=378)\end{array}$} & \multicolumn{2}{|c|}{$\begin{array}{c}\text { Age }>30 \text { years } \\
(n=1,457)\end{array}$} & \multicolumn{2}{|c|}{$\begin{array}{l}19-35 \text { years } \\
(n=473)\end{array}$} \\
\hline & $\%$ & $\begin{array}{c}\text { Percent of } \\
\text { cases }\end{array}$ & $\%$ & $\begin{array}{c}\text { Percent of } \\
\text { cases }\end{array}$ & $\%$ & $\begin{array}{l}\text { Percent of } \\
\text { cases }\end{array}$ & $\%$ & $\begin{array}{l}\text { Percent of } \\
\text { cases }\end{array}$ \\
\hline Nothing (0) & 8 & 17 & 11 & 23 & 7 & 16 & 11 & 22 \\
\hline Nature (1) & 13 & 29 & 10 & 21 & 14 & 31 & 10 & 21 \\
\hline Rest (2) & 14 & 31 & 12 & 25 & 15 & 33 & 13 & 28 \\
\hline Belief (3) & 9 & 20 & 7 & 15 & 9 & 21 & 8 & 16 \\
\hline Love (4) & 9 & 21 & 11 & 23 & 9 & 20 & 11 & 22 \\
\hline Death (5) & 3 & 6 & 2 & 3 & 3 & 7 & 2 & 3 \\
\hline Art (6) & 2 & 3 & 1 & 2 & 2 & 4 & .6 & 1 \\
\hline Dignity (7) & 3 & 6 & 3 & 7 & 3 & 7 & 4 & 7 \\
\hline Institution (8) & 13 & 28 & 12 & 25 & 13 & 29 & 12 & 24 \\
\hline Ritual (9) & 3 & 7 & 3 & 6 & 3 & 7 & 3 & 6 \\
\hline Finland (10) & .7 & 2 & .3 & .5 & .8 & 2 & .2 & .4 \\
\hline Individual (11) & 9 & 21 & 14 & 28 & 8 & 19 & 14 & 28 \\
\hline Others (12) & 6 & 14 & 4 & 8 & 7 & 15 & 4 & 9 \\
\hline Concept (13) & 7 & 15 & 10 & 20 & 6 & 14 & 8 & 17 \\
\hline Health (14) & .1 & .2 & 0 & 0 & .1 & .3 & 0 & 0 \\
\hline
\end{tabular}

Note. The $n$ refers to the number of meaning categories of responses in the entire sample and the subsamples, not the size of the sample (in reference to the Multiple Response Sets data used) Bold values refer to proportions mentioned in text. The names refer to short labels of the categories. The complete labels are: Nothing, doubt, difficult to say, difficult (0); Nature (1); Rest,

peace, the home as a location (2); Belief, religion (3); Love, close ones, home with family (4); Death, grave (5); Art, music, science (6); Human dignity, new life, children (7); Location, church, institution (8); Ritual (9); Finland, independence (10); Individual, myself, my opinions, thinking (11); Others, helping, contact (12); 'The sacred' as a concept (13); and Health (14). 
Table 2. Total Distribution in Meaning Categories of Responses According to Gender

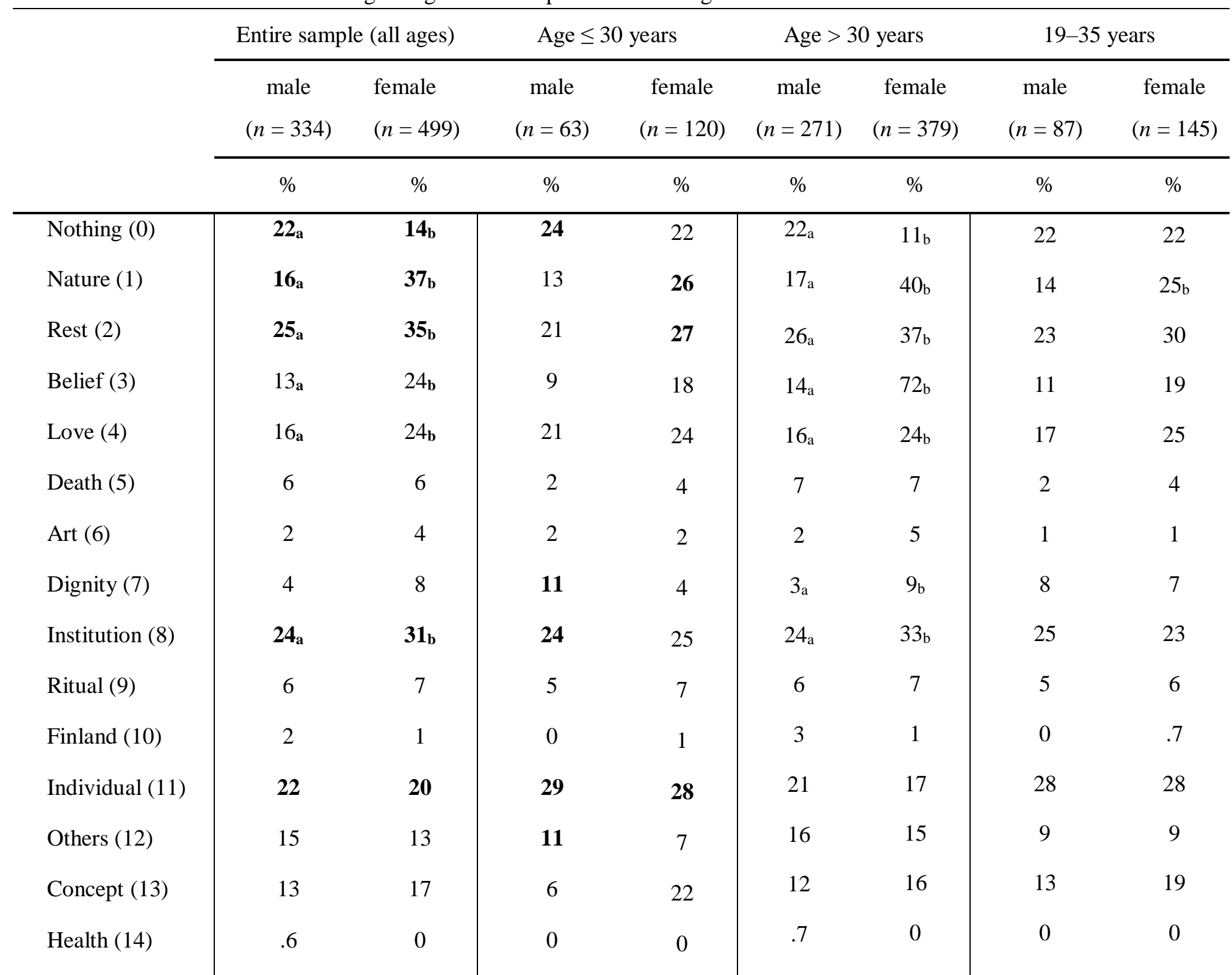

Note. The $n$ refers to the number of meaning categories of responses in the entire sample and the subsamples, not the size of the sample (in reference to the Multiple Response Sets data used). Bold values refer to proportions mentioned in text. Values in the same row not sharing the same subscripts are significantly different at the $p<.05$ level in the two-sided test of equality for column proportions. The names refer to short labels of the categories. The complete labels are: Nothing, doubt, difficult to say, difficult (0); Nature (1); Rest, peace, the home as a location (2); 
Table 3. Descriptive Information on Religiosity

\begin{tabular}{lccccccc}
\hline Variables & Scale & $\boldsymbol{M}$ & $\boldsymbol{S D}$ & $\mathbf{1 .}$ & $\mathbf{2 .}$ & $\mathbf{3 .}$ & $\mathbf{4 .}$ \\
\hline 1. Religiosity & $1-5$ & 3.89 & 1.06 & - & & & \\
2. Spirituality & $1-5$ & 3.07 & 1.05 & $.42^{*}$ & - & \\
3. Traditional religious practice & - & - & - & $.69^{* *}$ & $.43^{* *}$ & - & \\
4. Contemporary religious practice & - & - & - & .01 & $.26^{* *}$ & $.12^{*}$ & - \\
\hline
\end{tabular}

Note. Scale reverse-ordered with lower level indicating higher religiosity.

$* p<.05, * * p<.01$ 
Table 4. Total Distribution in Meaning Categories of Responses According to Religiosity Groupings of Young Adults

\begin{tabular}{|c|c|c|c|c|}
\hline & $\begin{array}{c}\text { Most religious } \\
\qquad(n=28)\end{array}$ & $\begin{array}{l}\text { Fairly religious } \\
\qquad(n=47)\end{array}$ & $\begin{array}{l}\text { Fairly unreligious } \\
\qquad(n=61)\end{array}$ & $\begin{array}{l}\text { Most unreligious } \\
\qquad(n=95)\end{array}$ \\
\hline & $\%$ & $\%$ & $\%$ & $\%$ \\
\hline Nothing (0) & $11_{\mathrm{a}, \mathrm{b}}$ & $13_{\mathrm{a}}$ & $16_{a, b}$ & $34_{b}$ \\
\hline Nature (1) & $32_{\mathrm{a}, \mathrm{b}}$ & $38 \mathrm{a}$ & $10_{\mathrm{b}}$ & $15_{b, c}$ \\
\hline Rest (2) & 32 a & 32 a & $23_{a}$ & 27 a \\
\hline Belief (3) & $57 \mathrm{a}$ & $15 \mathrm{~b}$ & $8 b$ & $10_{\mathrm{b}}$ \\
\hline Love (4) & $21_{a}$ & 30a & $23_{\mathrm{a}}$ & $18 \mathrm{a}$ \\
\hline Death (5) & 0 & $6 \mathrm{a}$ & $3 \mathrm{a}$ & $2 \mathrm{a}$ \\
\hline Art (6) & $4 a$ & $2 \mathrm{a}$ & $2 \mathrm{a}$ & 0 \\
\hline Dignity (7) & $14 \mathrm{a}$ & $9 \mathrm{a}$ & $7 \mathrm{a}$ & $5 \mathrm{a}$ \\
\hline Institution (8) & 39a & $32_{\mathrm{a}, \mathrm{b}}$ & $26_{a, b}$ & $14_{b}$ \\
\hline Ritual (9) & $4 a$ & $6 a$ & $10_{\mathrm{a}}$ & $3 \mathrm{a}$ \\
\hline Finland (10) & 0 & 0 & 0 & $1_{\mathrm{a}}$ \\
\hline Individual (11) & $21_{a}$ & $322_{a}$ & $26_{a}$ & 30a \\
\hline Others (12) & $7 \mathrm{a}$ & $17 \mathrm{a}$ & $5 \mathrm{a}$ & $8 a$ \\
\hline Concept (13) & $18 \mathrm{a}$ & $1_{\mathrm{a}}$ & $18 \mathrm{a}$ & $16_{a}$ \\
\hline Health (14) & 0 & 0 & 0 & 0 \\
\hline
\end{tabular}

Note. The $n$ refers to the number of meaning categories of responses in the religiosity groupings (in reference to the Multiple Response Sets data used). Bold values refer to proportions mentioned in text. Values in the same row not sharing the same subscripts are significantly different at the $p<.05$ level in the two-sided test of equality for column proportions. The names refer to short labels of the categories. The complete labels are: Nothing doubt, difficult to say, difficult (0); Nature (1); Rest, peace, the home as a location (2); Belief, religion (3); Love, close ones, home with family (4); Death, grave (5); Art music, science (6); Human dignity, new life, children (7); Location, church, institution (8); Ritual (9); Finland, independence (10); Individual, myself, my opinions, thinking (11); Others, helping, contact (12); 'The sacred' as a concept (13); and Health (14). 


\section{Notes}

${ }^{\mathrm{i}}$ The information in parentheses refers to gender $(\mathrm{M}=$ male, $\mathrm{F}=$ female $)$ and age.

ii The Chi-square test could not be used in all analyses because the assumptions were not valid.

\section{References}

Almeida, David M. and Wong, Jen D. (2009) 'Life Transitions and Daily Stress Processes', in Glen H. Elder, Jr. and Janet Z. Giele (eds) The Craft of Life Course Research, pp. 141162. New York: Guilford.

Ammerman, Nancy (ed) (2007) Everyday Religion: Observing Modern Religious Lives. New York: Oxford University Press.

Anttonen, Veikko (1996) 'Rethinking the Sacred: The Notions of 'Human Body' and 'Territory' in Conceptualizing Religion', in Thomas A. Idinopulos and Edward A. Yonan (eds) The Sacred and its Scholars: Comparative Methodologies for the Study of Primary Religious Data, pp. 36-64. Leiden: E. J. Brill.

Anttonen, Veikko (2000) 'Toward a Cognitive Theory of the Sacred: An Ethnographic Approach', Folklore 14: 41-48.

Arnett, Jeffrey J. (2004) Emerging Adulthood: The Winding Road from the Late Teens Through The Twenties. New York: Oxford University Press.

Arweck, Elisabeth and Keenan, William (ed) (2006) Materializing Religion. Aldershot: Ashgate.

Barrett-Lennard, Godfrey T. (1998) Carl Rogers' Helping System: Journey and Substance. London: Sage.

Bergman, Siguard, Scott, Peter Manley, Jansdotter Samuelsson, Maria and Bedford-Strohm, Heinrich (eds) (2009) Nature, Space and the Sacred. Farnham and Burlington: Ashgate.

Brewer, Marilun B. and Brown, Rupert J. (1998) 'Intergroup Relations', in Daniel T. Gilbert and Susan T. Fiske (eds) The Handbook of Social Psychology 2(4): 554-594. Boston: McGrawHill.

Chan, Melissa, Tsai, Kim and Fuligni, Andrew (2015) 'Changes in Religiosity Across the Transition to Young Adulthood', Journal of Youth and Adolescence 44(8): 1555-1566.

Cobb, Nancy J. (2010) Adolescence. Sunderland, MA: Sinauer Associates.

Collins, Peter (2008) 'Accommodating the Individual and the Social, the Religious and the Secular', in Abby Day (ed) Religion and the Individual: Belief, Practice, Identity, pp. 143-156. Aldershot: Ashgate.

Collins-Mayo, Sylvia and Dandelion, Pink (eds) (2016) Religion and Youth. Theology and Religion in Interdisciplinary Series in Association with the BSA Sociology of Religion Study Group. Farnham, UK: Ashgate.

Dawson, Lorne L. (2006) 'Privatization, Globalization, and Religious Innovation', in James A. Beckford and John Walliss (eds) Theorizing Religion: Classical and Contemporary Debates, pp. 105-119. Aldershot: Ashgate.

Day, Abby and Cotter, Christopher R. (eds) (2013) Ashgate AHRC/ESRC Religion and Society Series: Social Identities Between the Sacred and the Secular. Farnham, UK: Ashgate.

Deacy, Cristopher and Arweck, Elisabeth (ed) (2009) Exploring Religion and the Sacred in a Media Age. Farnham: Ashgate.

De Haan, Laura G., Yonker, Julie E. and Affholter, Carolyn (2011) 'More than Enjoying the Sunset: Conceptualization and Measurement of Religiosity for Adolescents and Emerging Adults and its Implications for Developmental Inquiry', Journal of Psychology \& Christianity 30(3): 184-195. 
Denton, Melinda L., Pearce, Lisa D. and Smith, Christian (2008) 'Religion and Spirituality on the Path Through Adolescence', Research Report Number 8. National Study of Youth and Religion, University of North Carolina at Chapel Hill.

Desmond, Scott A., Kikuchi, George and Budd, Kristen (2010) 'Does Change in Teenage Religiosity Predict Change in Marijuana Use Over Time?' Interdisciplinary Journal of Research on Religion 6: 1-30.

Dobbelaere, Karel (2002) Secularization: An Analysis at Three Levels. Oxford: Peter Lang. Durkheim, Émile (1995/1912) The Elementary Forms of Religious Life. Transl. Joseph Ward Swain. New York: Free Press.

Elder, Glen H., Jr. (1998) 'The Life Course and Human Development', in William Damon and Richard M. Lerner (eds) Theoretical Models of Human Development. Handbook of Child Psychology, Vol. 1., pp. 939-991. Hoboken, NJ: Wiley.

Ford, Jason A. and Hill, Terrence D. (2012) Religiosity and Adolescent Substance Use: Evidence From the National Survey on Drug Use and Health. Substance Use \& Misuse 47(7): 787798.

Fowler, James W. (2001) 'Faith Development Theory and the Postmodern Challenges', International Journal for the Psychology of Religion 11: 159-172.

Furseth, Inger (2006) From Quest for Truth to Being Oneself: Religious Change in Life Stories. Frankfurt am Main: Peter Lang.

Furstenberg, Frank F. (2001) 'Adolescence, Sociology of', in Neil J. Smelser and Paul B. Baltes (eds) International Encyclopedia of the Social \& Behavioral Sciences, pp. 94-97. Oxford: Elsevier.

Heelas, Paul and Woodhead, Linda, with Seel, Benjamin, Szerszynski and Tusting, Karin (2005) The Spiritual Revolution: Why Religion is Giving Way to Spirituality. Oxford: Blackwell.

Heidegger, Martin (1962) Being and Time. Trans. by John Macquarrie and Edward Robinson. London: SCM Press.

Henriksen, Jan-Olav (2016) 'Everyday Religion as Orientation and Transformation: A Challenge to Theology', Nordic Journal of Religion and Society 29(1): 36-51.

Huculak, Susan and McLennan, John D. (2010) “"The Lord is my Shepherd”: Examining Spirituality as a Protection against Mental Health Problems in Youth Exposed to Violence in Brazil', Mental Health, Religion \& Culture 13(5): 467-484.

Hull, Shawnika J., Hennessy, Michael, Bleakley, Amy, Fishbein, Martin and Jordan, Amy (2011) 'Identifying the Causal Pathways from Religiosity to Delayed Adolescent Sexual Behavior', Journal of Sex Research 48(6): 543-553.

Idinopulos, Thomas A. and Yonan, Edward, A. (eds) (1996) The Sacred and its Scholars: Comparative Methodologies for the Study of Primary Religious Data. Leiden: E. J. Brill.

Ilg, Wolfgang and Schweitzer, Friedrich (2010) 'Researching Confirmation Work in Europe: The Need for Multi-Level Analysis for Identifying Individual and Group Influences in NonFormal Education', Journal of Empirical Theology 23(2): 159-178.

Isralowitz, Richard and Reznik, Alexander (2015) 'Impact of Religious Education and Religiosity on Adolescent Alcohol Use and Risk-Taking Behavior', Religious Education 110(3): 303310.

Jones, Robert A. (1986) Émile Durkheim: An Introduction to Four Major Works. Beverly Hills, CA: Sage.

King, Pamela E., Clardy, Casey E. and Ramos, Jenel S. (2014) 'Adolescent Spiritual Exemplars: Exploring Spirituality in the Lives of Diverse Youth', Journal of Adolescent Research 29(2): 186-212.

Kirkon väkiluku 2013 [Church population 2013] (2014). 'Väestönmuutokset 2013' [Population change 2013], URL (consulted August, 2015): http://sakasti.evl.fi/sakasti.nsf/start 
Knott, Kim (2005) The Location of Religion: A Spatial Analysis. London and Oakville, CT: Equinox.

Lerner, Richard M., Roeser, Robert W. and Phelps, Erin (2008) Positive Youth Developmen and Spirituality: From Theory to Research. West Conshohocken, PA: Templeton Foundation Press.

Lewis, James R. and Hammer, Olav (ed) (2008) The Invention of Sacred Tradition. Cambridge: Cambridge University Press.

Lövheim, Mia (2012) 'Ungas religiositet: Tidigare forskning och nya frågor' [Young people's religiosity: Previous research and new questions], in Mia Lövheim and Jonas Bromander (eds) Religion Som Resurs? Existentiella Frågor Och Värderingar i Unga Svenskars Liv [Religion as a Resource? Existential Questions and Values in the Life of Swedish Youth], pp. 77-106. Skellefteå: Artos.

Lynch, Gordon (ed) (2007) Between Sacred and Profane. Researching Religion and Popular Culture. London: I. B. Tauris.

Manlove, Jennifer, Logan, Cassandra, Moore, Kristin A. and Ikramullah, Erum (2008) 'Pathways from Family Religiosity to Adolescent Sexual Activity and Contraceptive Use', Perspectives on Sexual \& Reproductive Health 40(2): 105-117.

Marttinen, Elina, Dietrich, Julia and Salmela-Aro, Katariina (2016) 'Dark Shadows of Rumination: Finnish Young Adults’ Identity Profiles, Personal Goals and Concerns', Journal of Adolescence 47: 185-196.

McGuire, Meredith (2008) Lived Religion: Faith and Practice in Everyday Life. New York: Oxford University Press.

Mikkola, Teija, Niemelä, Kati and Petterson, Juha (2007) The Questioning Mind. Tampere: The Church Research Institute.

Miles, Stephen (2000) Youth Lifestyles in a Changing World. Buckingham: Open University Press.

Niemelä, Kati (2011) 'Heikkeneekö uskonnollisuus ikäryhmissä?: Uskonnollinen kasvatus ja sen merkitys uskonnollisuuden selittäjänä' [Does religiosity decrease in age groups?: Religious education and its significance in explaining religiosity], in Kimmo Ketola, Kati Niemelä, Harri Palmu and Hanna Salomäki (eds), Uskonto suomalaisten elämässä: Uskonnollinen kasvatus, moraali, onnellisuus ja suvaitsevaisuus kansainvälisessä vertailussa [Religion in Finns' lives: Religious education, morality, happiness and tolerance in international comparison]. Tampere: Finnish Social Science Data Archive.

Niemelä, Kati (2015) 'No Longer Believing in Belonging: A Longitudinal Study of Finnish Generation Y from Confirmation Experience to Church-leaving', Social Compass 62(2): $172-186$.

Otto, Rudolf (1923) The Idea of the Holy. London: Oxford University Press.

Paden, William E. (1994) Religious Worlds: The Comparative Study of Religion. Boston: Beacon.

Paden, William E. (1996) 'Sacrality as Integrity', in Thomas A. Idinopulos and Edward A. Yonan (eds) The Sacred and its Scholars, pp. 3-18. Leiden: E. J. Brill.

Paden, William E. (2009) 'Reappraising Durkheim for the Study and Teaching of Religion', in Peter Clark (ed) The Paden Handbook of the Sociology of Religion, pp. 941-961. Oxford: Oxford University Press.

Pargament, Kenneth I. (2007) Spiritually Integrated Psychotherapy: Understanding and Addressing the Sacred. New York: Guilford.

Robinson, Oliver C. (2015) 'Emerging Adulthood, Early Adulthood and Quarter-Life Crisis: Updating Erikson for the Twenty-First Century’, in Rita Žukauskiene (ed) Emerging Adulthood in a European context, pp. 17-30. New York: Routledge.

Roeser, Robert W., Isaac, Sonia S., Abo-Zena, Mona, Brittian, Aerika and Peck, Stephen C. (2008) 'Self and Identity Processes in Spirituality and Positive Youth Development', in Richard M. Lerner, Robert W. Roeser and Erin Phelps (eds) Positive Youth Development: From Theory 
to Research, pp 74-105. West Conshohocken, PA: Templeton Foundation Press.

Roof, Wade C. (1993). A Generation of Seekers. San Francisco, CA: Harper.

Sered, Susan Starr (1994) Priestess, Mother, Sacred Sister. Religions Dominated by Women. London and New York: Oxford University Press.

Settersten, Richard A., Jr. (2003) 'Propositions and Controversies in Life-Course Scholarship', in Richard A. Settersten, Jr. (ed) Invitation to the Life Course: Toward New Understandings of Later Life, pp. 15-45. New York: Baywood.

Sjöborg, Anders (2013) 'Mapping "Religion" - or "Something, I Don't Know What"?

Methodological Challenges Exploring Young Peoples' Relations with "Religion", in Abby Day and Giselle Vincett (eds) Social Identities Between the Sacred and the Secular, pp. 191-200. Ashgate AHRC / ESRC Religion and Society Series. Surrey: Ashgate.

Starr, Sharon S. (2008) 'Authenticity: A Concept Analysis', Nursing Forum 43(2): 55-62.

Storm, Ingrid and Voas, David (2012) 'The Intergenerational Transmission of Religious Service Attendance', Nordic Journal of Religion \& Society 25(2): 131-150.

Taylor, Charles (1991) The Ethics of Authenticity. Cambridge: Harvard University Press.

Uecker, Jeremy E., Regnerus, Mark D. and Vaaler, Margaret L. (2007) 'Losing My Religion: The Social Sources of Religious Decline in Early Adulthood', Social Forces 85(4): 1667-1692.

Voas, David and Day, Abby (2010). 'Recognizing Secular Christians: Toward an Unexcluded Middle in the Study of Religion'. ARDA Guiding Paper, URL (consulted March, 2015): http://www.thearda.com/rrh/papers/guidingpapers/Voas.pdf

Willaime, Jean-Paul (2006) 'Religion in Ultramodernity', in James A. Beckford and John Wallis (eds) Theorizing Religion: Classical and Contemporary Debates, pp. 77-89. Aldershot: Ashgate.

Woodhead, Linda (2013) 'Gender Differences in Religious Practice and Significance', International Advances in Engineering and Technology 13: 58-85. 